\title{
Omega-3 fatty acids in schizophrenia Part II: Clinical applications
}

\author{
Kwasy tłuszczowe omega-3 w schizofrenii \\ Część II: Możliwości zastosowania klinicznego
}

\section{Joanna Róg ${ }^{1} \mathrm{~A}, \mathrm{~B}, \mathrm{C}, \mathrm{D}, \mathrm{E}, \mathrm{F}$, Ewa Stelmach ${ }_{\mathrm{B}, \mathrm{C}}$, Bożena Śpila ${ }_{\mathrm{B}, \mathrm{C}}$, Jacek Gajewski ${ }_{\mathrm{B}, \mathrm{C}}$, Dariusz Juchnowicz ${ }^{6}{ }_{D, E}$, Aleksandra Korzeniowska ${ }^{4}{ }_{B, C}$, Joanna Tomaka ${ }^{2}{ }_{\mathrm{B}, \mathrm{C}}$, Hanna Karakuła-Juchnowicz ${ }^{2,3}$ A,B,C,D,E,G}

1. Faculty of Human Nutrition and Consumer Sciences, Warsaw University of Life Sciences 2. I Department of Psychiatry, Psychotherapy and Early Intervention, Medical University of Lublin

3. Department of Clinical Neuropsychiatry, Medical University in Lublin

4. II Department of Psychiatry and Psychiatric Rehabilitation, Medical University of Lublin 5. Psychiatric Outpatient Department of the Independent Public Clinical Hospital No. 1 in Lublin

6. Department of Psychiatric Nursing, Medical University of Lublin

\begin{abstract}
$\Omega-3$ unsaturated fatty acids are compounds belonging to the group of essential fatty acids (EFAs). The history of the discovery of EFAs dates back to the 1930s of the twentieth century, however, growing interest in $\omega-3$ EFAs in the context of mental health has been observed since the year 2000. In view of their multidirectional action, these compounds are a promising form of adjunctive therapy of many illnesses, including psychiatric disorders. The present article aims to review the literature on the clinical applicability of $\omega-3$ EFAs in treating schizophrenia. We present the results of preclinical studies in this area and the mechanisms of $\omega-3$ EFAs action discussed by the authors. The randomized controlled trials (RCTs) evaluating the possibility of using $\omega-3$ EFAs in schizophrenia are characterized in detail. The results of the tests are not clear, which may result from the methodological diversity of interventions made. $\Omega-3$ EFAs seem to be a promising form of adjunctive therapy of schizophrenia. Further research is needed, which will allow for defining groups of patients in which intervention will bring the expected results.
\end{abstract}

Keywords: schizophrenia, omega-3, omega -3 essential fatty acids fatty acids, docosahexaenoic acid, eicosapentaenoic acid, randomized clinical trial, supplementation

\section{Streszczenie}

Nienasycone kwasy tłuszczowe $\omega$-3 to związki należące do grupy niezbędnych nienasyconych kwasów tłuszczowych (NNKT). Historia odkrycia NNKT sięga lat 30. XX wieku, jednak rosnące zainteresowanie NNKT $\omega-3 \mathrm{w}$ kontekście zdrowia psychicznego obserwuje się od roku 2000. Ze względu na wielokierunkowość działania związki te stanowią obiecującą formę koterapii wielu chorób, w tym zaburzeń psychicznych. Celem artykułu był przegląd piśmiennictwa dotyczącego klinicznych możliwości zastosowania NNKT $\omega$-3 $\mathrm{w}$ terapii schizofrenii. Przedstawiono wyniki badań przedklinicznych w tym zakresie oraz omówione przez autorów mechanizmy działania NNKT- $\omega$-3. Szczegółowo scharakteryzowano randomizowane kontrolowane badania kliniczne (RCTs) oceniające możliwość zastosowania NNKT $\omega-3 \mathrm{w}$ schizofrenii. Wyniki badań nie są jednoznaczne, co wynikać może z różnorodności metodologicznej przeprowadzanych interwencji. NNKT $\omega-3$ wydają się być obiecującą formą współleczenia schizofrenii. Konieczne są dalsze badania, które pozwolą na określenie grup chorych, w których interwencja przyniesie oczekiwane rezultaty.

Słowa kluczowe: schizofrenia, omega 3, niezbędne nienasycone kwasy tłuszczowe omega 3, kwas dokozaheksaenowy, kwas eikozapentaenowy,randomizowane badanie kliniczne, suplementacja

\section{Introduction}

Omega-3 fatty acids $(\omega-3)$ belong to the group of essential fatty acids (EFAs). This means that the human body does not have the capacity of their synthesis and it is necessary to provide them with food [1]. The history of EFAs dates back to the 1930s of the twentieth century, when American scientists Burr and Evans observed symp- toms in rats caused by a deficiency of EFAs. A breakthrough in research on EFAs were the reports dated to the 1980s of the twentieth century of their role in the prevention of cardiovascular diseases [2]. The first evidence of correlations between EFA and the mental health appeared after the year 2000 , and the number of publications in this field continues to grow. The interest in EFA is due to the high content of 
essential fatty acids in the brain and their effects on the CNS function [3]. $\Omega$-3 EFAs can favorably influence the course of a number of concomitant to mental illness disorders. An important role of $\omega-3$ EFAs is attributed to prevention and treatment of the metabolic syndrome components dyslipidemia, abnormal glucose metabolism and hypertension [4], as well as cognitive disorders [4,5]. The role of $\omega-3$ EFAs in the modulation of the immune system was also demonstrated [6], including the regulation of the proinflammatory and anti-inflammatory cytokine markers $[7,8]$. Due to their multidirectional action, $\omega-3$ EFAs are worthwhile form of adjunctive therapy of mental disorders, including schizophrenia.

\section{Aim}

The paper reviews the literature on the clinical use of essential fatty acids (EFAs) omega $3(\omega-3)$, with particular emphasis on docosahexaenoic acid (DHA) and the eicosapentaenoic acid (EPA), in the treatment of schizophrenia and schizophrenia spectrum disorders.

\section{Methods}

A review of available papers on the discussed issues was made using electronic databases Medline and the Google Scholar, using the time descriptor 2000 - September 2016 and the keywords: schizophrenia, omega-3, omega -3 essential fatty acids fatty acids, docosahexaenoic acid, eicosapentaenoic acid, $\alpha$-linolenic acid, randomized clinical trial, supplementation.

The present study has been divided into the following, logically-related subsections:

1. Data from preclinical studies

2. Data from randomized controlled trials (RCTs) on the efficacy and safety of $\omega-3$ EFAs in tests (Table 1 presents the summary of the analyzed papers):

2.1. High risk study

2.2. During the first episode of psychosis

2.3. In preventing further psychotic episodes

2.4. In monotherapy

2.5. In the drug resistance

2.6. Data from a meta-analysis

2.7. The observed side effects

3. Conclusions

\section{Data from preclinical studies}

An important part of the knowledge of the biomedical areas begins with research based on animal models. Evaluation of the efficacy of interventions and their safety allows for subsequent testing in humans. The animal studies, in which the efficacy of schizophrenia treatment is assessed, provides some difficulties [9]. Lack of objective markers of mental disorders, the diagnosis based on the finding of psychopathological symptoms and low specificity of symptoms, prevent the creation of an optimal animal model in relation to this group of disorders [10].

In the intervention studies in the animal model, which were evaluating the efficacy of supplementation with $\omega-3$ EFAs on schizophreniform symptoms, the disease in animals was induced by injection of ketamine [11-14] or amphetamine [15]. Supplementation with $\omega$-3 EFAs preceded the consecutive final stage of the experiment, the induction of symptoms [11-15].

In the study of Zugano et al., administration of $\omega-3$ EFAs inhibited the activity of an enzyme involved in the hydrolysis of acetylcholine (acetylcholinesterase) in the prefrontal cortex, striatum and hippocampus [13]. Abnormal cholinergic transmission and the decrease in the concentration of the neurotransmitter correlate positively with cognitive dysfunction $[16,17]$.

In another study there was investigated the effect of $\omega-3$ EFAs on brain-derived neurotrophic factor (BDNF) levels and the compounds of proinflammatory character IL-1 $\beta$ and IL6 [14]. In patients suffering from schizophrenia, excessive secretion of proinflammatory cytokines is observed. These substances are able to penetrate the blood-brain barrier and induce changes in the CNS [18]. BDNF is involved in promoting the growth and the plasticity of neurons, and people with schizophrenia have significantly lower levels of BDNF in the plasma and serum compared with healthy controls [19]. In the model study $\omega-3$ EFAs did not affect the secretion of interleukins. The authors of the study showed, however, that supplementation with $\omega-3$ EFAs prevented the decrease of BDNF in prefrontal cortex of rats [14].

Also Gama et al. observed changes in the BDNF level caused by supplementation with $\omega-3$ EFAs. The supplementation caused the increase in the BDNF level. No changes in the BDNF mRNA expression were observed. In rats subjected to intervention, a decrease in the severity of positive, negative and cognitive symptoms and the locomotor hyperactivity was shown. Short-term, longterm and working memories and reduced interaction with other individuals caused by disease also improved [11].

The impact of $\omega-3$ EFAs on the prepulse inhibition (PPI), i.e. weakening of the reaction caused by weak stimulation prior to a stronger stimulus was studied by Zugano et al. The supplementation resulted in a partial elimination of the PPI. In the study, the $\omega-3$ EFAs counteracted the decrease in the glutathione peroxidase (GPx) activity in the striatum and the hippocampus and inhibited GPx hyperactivity in the prefrontal cortex. The supplementation intensified ketamine-induced increase in superoxide dismutase (SOD) in the hippocampus. In the prefrontal cortex $\omega-3$ EFAs decreased the observed in the affected rats SOD 
hyperactivity. Animals from the test group also were characterized by a lower activity of catalase (CAT) in the prefrontal cortex compared to the group with disease symptoms and the control group. According to the authors, the observed in the study enzyme regulation heterogeneity was associated with the brain-region-dependent activity of antioxidant enzymes and specificity with regard to CNS structures of $\omega-3$ EFAs effects [12]. The authors of the study also showed protective effect of eicosapentaenoic acid (EPA) and the docosahexaenoic acid (DHA) in terms of unfavorable phenomena of peroxidation of lipids and proteins observed among patients treated with antipsychotics. The supplementation prevented damage of lipids in the hippocampus and the striatum, or damage to proteins in the prefrontal cortex and striatum [12].

In the studies the efficacy of $\omega-3$ EFAs with other forms of pharmacotherapy was compared. Rats receiving supplementation were characterized by higher scores in the test assessing the declarative memory and the spatial orientation compared to the untreated animals. However, this effect was dependent on the applied test substance. Rats receiving EPA and DHA had significantly better results compared to those receiving risperidone, and similar results to animals receiving COX-2 selective nonsteroidal anti-inflammatory drug- celecobix. Supplementation with $\omega-3$ EFAs contributed to improvement of main memory and recognition memory (the time required to investigate an unknown individual) of animals [15].

Data from animal studies showed that $\omega-3$ EFAs have a positive impact on reducing psychopathological symptoms and pathological biochemical changes of the brain in schizophrenia. The conclusions of preclinical studies should be treated with caution, and their results should not be directly extrapolated to the human body. These methods have some limitations, mainly based on the assumption that the structure and functions of the brain of animals and humans are similar, and their mechanism of action is the same. The structure of the human CNS differs from the CNS in rat. Similar differences relate to the complexity of behavior and thought processes [20]. The supplementation used in these studies was approx. $0.8 \mathrm{~g}$ of $\omega-3$ EFAs / $\mathrm{kg}$ of animal body weight [11-15]. Using such an amount of $\omega-3$ EFAs in humans, a patient weighing $70 \mathrm{~kg}$ should receive a dose in the amount of $56 \mathrm{~g}$, while the doses used in the RCT are much smaller and are ranging from $0.5 \mathrm{~g}$ to $4 \mathrm{~g}$.

\section{Data from randomized controlled trials (RCTs) on the efficacy and safety of $\omega-3$ EFAs}

\subsection{High risk study}

Only one study carried out by Amminger et al. in 2010 evaluated the effects of supplementation with $\omega-3$ EFAs in the prevention of psychotic disorders in a high- risk group of developing psychosis. During the 12 -week intervention participants received $1200 \mathrm{mg}$ of $\omega-3$ EFAs (700 mg EPA and + 480 mg DHA) or coconut oil as placebo. The primary endpoint of the study was to develop a psychotic disorder. The health status of the participants was assessed after 40 weeks. Seventy-six of 81 patients remained in the study. In 2 patients in the study group (4.9\%) progression of disease symptoms was noted, and in the group receiving placebo, progression was observed in 11 patients (27.5\%). Supplementation with $\omega-3$ EFAs reduced the overall severity of psychopathological symptoms measured by PANSS, including all of its subscales: positive symptoms, negative and the general symptoms. In the study group receiving EFAs, improvement in the functioning measured by the GAF scale was shown compared to placebo group [21].

Amminger et al. continued their study, evaluating long-term effect of $\omega-3$ EFAs in high-risk patients [33]. The obtained by the authors results confirmed the presented in the first publication [21] conclusions concerning a protective effect of EPA and DHA. Seven years after the completion of supplementation, in 4 (7.9\%) patients in the group receiving EFAs and in $16(40 \%)$ patients in the placebo group a psychotic episode appeared.

Significant differences in the improvement of the clinical condition of the patients were shown. Patients with $\omega-3$ EFAs supplementation showed improvement in the functioning measured by the GAF scale and psychopathological symptoms measured by PANSS and all its subscales compared with the placebo group. In the course of the ongoing seven years of follow-up 10 of 34 (29.4\%) patients in the study group were taking antipsychotics. In the placebo group, 19 of 35 (54.3\%) patients used these drugs [33].

\subsection{First episode}

In 2016 Pawełczyk et al., published the results of RCT in the group of 71 patients with a first episode of schizophrenia. During the 26-week intervention, the participants received $2200 \mathrm{mg}$ of $\omega$-3 EFAs (1320 mg EPA + $880 \mathrm{mg}$ DHA) or olive oil as a placebo. In the study 65 participants remained. After 6 months of intervention significant (25\%) decrease in the severity of psychopathological symptoms and general symptoms subscale measured by PANSS scale was observed. Response to treatment was observed in $33.3 \%$ of those treated with $\omega-3$ EFAs in comparison with the $5.7 \%$ placebo-taking patients. The reduction of depression symptoms as measured by the CDSS scale, increase in the global assessment of functioning (GAF scale) and the improvement of the clinical general impression (CGI-S scale) were also demonstrated [22].

\subsection{Preventing subsequent psychotic episodes}

So far, most of the data on the effect of supplementation with $\omega-3$ EFAs on the course of schizophrenia comes 
from studies in which $\omega$-3 EFAs are used as a complementary treatment to standard pharmacotherapy. The primary endpoint of the study was the clinical status and severity of psychopathological symptoms of patients.

Fenton et al., supplemented $\omega-3$ EFAs in the group of patients with schizophrenia or schizoaffective disorder. Thirty-four patients (39\%) were taking risperidone, olanzapine and quetiapine, 24 patients (28\%) were taking clozapine, while 19 patients (22\%) used two antipsychotics. Supplementation with EPAs in the amount of $3000 \mathrm{mg}$ lasted 16 weeks and 87 of the 90 people remained in the study. The authors found no beneficial effects arising from supplementation with $\omega$-3 EFAs [23].

Peet et al. compared clinical efficacy of the $2000 \mathrm{mg}$ EPA and 2000 mg DHA in 55 patients. Corn oil was used as a placebo. The authors of the study did not provide information regarding pharmacotherapy used by the participants of the study. Forty-five people remained in the intervention lasting 12 weeks. The group receiving EPA showed a significant reduction in the severity of psychopathological symptoms compared to the control group and the PANSS subscale of positive symptoms as compared to the DHA supplemented group [24].

The study of Emsley et al. involved 40 patients. Eighteen (45\%) patients were taking clozapine, the other study participants used the $1^{\text {st }}$ generation antipsychotic drugs. The study group received $3000 \mathrm{mg}$ EPA for 12 weeks, and paraffin was used as a placebo. The authors evaluated the severity of extrapyramidal symptoms. Patients supplemented with EPA showed a significant decrease in the severity of psychopathological symptoms and in PANSS general symptoms subscale compared to placeboreceiving patients. In addition, supplementation with EPA caused a decrease in the severity of dyskinesias [25].

Bentsen et al. apart from $\omega-3$ EFAs studied the effect of supplementation with two compounds having antioxidant effects - vitamin C and vitamin E. Ninety-nine patients suffering from schizophrenia spectrum disorders were randomly assigned to one of these groups - placebo group, supplemented with $\omega$-3 EFAs, supplemented with vitamins or supplemented with $\omega-3$ EFAs and vitamins simultaneously. The applied dose was $2000 \mathrm{mg}$ EPA, and paraffin oil was used as a placebo. Among the patients participating in the intervention, 51 (52\%) were taking clozapine or olanzapine. Supplementation period lasted 16 weeks and 72 patients remained in the study. In patients supplemented with EPA, there was observed a decrease in the severity of psychopathological symptoms measured by PANSS and of positive symptoms scale. This effect was observed only in patients with poor $\omega$-3 EFAs status [26].

Research by Jamilian et al. lasted for eight weeks and comprised 60 people. Enrolled for the study patients were treated with olanzapine, risperidone or clozapine. Thirty patients received $1000 \mathrm{mg}$ of $\omega$-3 EFAs. Severity of the symptoms was measured at baseline and 2, 4, 6 and 8 weeks after the onset of treatment. After week 4, a decrease in the severity of symptoms in total PANSS subscale was demonstrated and after 6 weeks, a decrease in the severity of psychopathological symptoms in PANSS scale was shown [27].

\subsection{Efficacy of EFAs monotherapy}

The efficacy of $\omega-3$ EFAs as a monotherapy for schizophrenia has been rated so far in two studies: Peet et al, in 2001 [24] and Emsley et al. in 2002 [25]. The study by Peet et al., involved a group of 30 newly diagnosed or during the consecutive episode of illness patients with schizophrenia: 9 people had never been taking neuroleptics and other participants in the study had not used pharmacotherapy for a minimum of two weeks before the beginning of the intervention. The patients received 2000 mg EPA, or the same amount of corn oil (as a placebo) over a period of three months. Twenty-six patients remained in the study. In the group receiving EPA at the end of protocol, 6 of 14 patients did not require antipsychotic treatment. In the control group all participants (12 people), returned to the traditional forms of therapy. Patients in the treatment group showed a significant reduction of psychopathological symptoms (total score) in PANSS total and positive symptoms subscale. Response to treatment, defined as more than $50 \%$ reduction in PANSS positive symptoms subscales, was shown in 2 patients in the placebo group and in 8 patients receiving EPA [24].

The second RCT, in which there was studied the effect of $\omega-3$ EFAs as the only form of therapy for schizophrenia, was the intervention carried out by Emsley et al., involving 33 patients after the first episode of the disease, in whom treatment with antipsychotics brought the expected results. Patients received $\omega-3$ EFAs in a dose 3300 mg (2000 mg EPA +1000 mg DHA + 300 mg ALA), or olive oil as a placebo for six months. Relapse was observed in 19 out of 21 participants in the study group (90\%) compared to 9 out of 12 (75\%) patients in the placebo group. One patient from group receiving $\omega-3$ EFAs remained in remission for 2 years. There was no difference in length of remission in the subgroups [28].

\subsection{Efficacy of EFAs in the case of confirmed drug resistance in schizophrenia}

Among the 115 participants in the study carried out by Peet and Horrobin there was a group of 31 patients treated with clozapine. In the enrolled subjects, despite pharmacotherapy, high severity of psychopathological symptoms was observed (on average a score of 78 points in the PANSS scale). 
The applied dose of EPA in the study was 1000, 2000 and 4000 $\mathrm{mg}$ and paraffin was used as a placebo. After 12 weeks of supplementation, patients receiving EPA exhibited a decrease in the severity of psychopathology symptoms in PANSS and general symptoms subscale as compared to the placebo group. The effect was achieved in the group receiving $2000 \mathrm{mg}$ [29]. One of the side effects of using clozapine is an increase in the level of blood triglycerides [30]. In the study, supplementation with EPA in a dose of 2000 or 4000 mg contributed to eliminating adverse effects of pharmacotherapy [29].

\subsection{Data from meta-analyses}

The first meta-analysis on essential fatty acids in schizophrenia was conducted in 2006. The authors on the basis of three publications (a group of patients $n=152$ ) demonstrated a significant decrease in psychopathological symptoms in the group supplemented with EPA compared to placebo -6.33 (95\% CI: -11.34 - -1.32) [31].

In 2012, Berger et al., analyzed the data from 7 studies evaluating the clinical efficacy of EPA in patients with schizophrenia (treated chronically and in the first episode of the disease). Meta-analysis included 167 patients receiving placebo and 168 subjects receiving EPA supple- mentation. The authors did not show beneficial effects of EPA supplementation in patients with schizophrenia. The authors in the conclusions suggested that due to the insufficient evidence, especially concerning the long-term supplementation and the use of $\omega-3$ EFAs in the prevention of recurrences after the first psychotic episode, further research in this area is needed [32].

\subsection{Side effects during the use of $\omega-3$ EFAs}

In two studies, the side effects of the use of $\omega$-3 EFAs were assessed using the Udvalg for Kliniske Undersøgelser scale [21, 22]. Pawelczyk et al. showed that patients receiving $\omega-3$ EFAs showed a greater tendency to constipation compared to patients receiving placebo [22]. In the study by Amminger there was no difference in reported symptoms of side effects between the two groups [21]. Bentsen et al.using USERS scale (UKU Side Effect Rating Scale) showed no adverse effects of supplementation with $\omega-3$ EFAs [26]. Peet and Horrobin measured side effects of supplementation using LUNSERS scale (The Liverpool University Neuroleptic Side Effect Rating Scale), and the results did not differ between the groups. The most commonly reported side effects were mild diarrhea and nausea [29].

Table 1. Randomized controlled trials, double-blind (RCTs) - the efficacy of $\omega$-3 EFAs in the treatment of schizophrenia.

\begin{tabular}{|c|c|c|c|c|c|c|c|c|c|c|c|}
\hline \multirow{3}{*}{$\begin{array}{l}\text { AUTHOR, } \\
\text { YEAR }\end{array}$} & \multicolumn{3}{|c|}{$\begin{array}{c}\text { RESEARCH } \\
\text { PARTICIPANTS } \\
\end{array}$} & \multicolumn{3}{|c|}{ SUPPLEMENTATION } & \multicolumn{5}{|c|}{ OUTCOME MEASURE } \\
\hline & \multirow[b]{2}{*}{$\begin{array}{c}\mathrm{N} \\
(\mathrm{SG} / \mathrm{CG})\end{array}$} & \multirow[b]{2}{*}{$\mathrm{F}: \mathrm{M}$} & \multirow[b]{2}{*}{ AGE } & \multirow[b]{2}{*}{$\begin{array}{l}\text { PERIOD } \\
\text { (WEEK) }\end{array}$} & \multirow[b]{2}{*}{ DOSE (MG/D) } & \multirow[b]{2}{*}{$\begin{array}{l}\text { TOOLS AS- } \\
\text { SESSING } \\
\text { EFFICACY }\end{array}$} & \multicolumn{4}{|c|}{ PANSS } & \multirow[t]{2}{*}{$\begin{array}{l}\text { OTHER } \\
\text { SCALES }\end{array}$} \\
\hline & & & & & & & 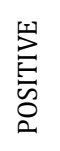 & 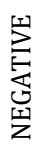 & 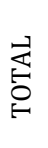 & $\sum_{\substack{n \\
n}}$ & \\
\hline Peet et al., 2001a & $15 / 14 / 16^{*}$ & $18 / 11$ & $31-56$ & 12 & $2000 \mathrm{EPA}$ & PANSS & $\downarrow$ & BZ & $\mathrm{BZ}$ & $\downarrow$ & - \\
\hline Peet et al., $2001 b$ & $15 / 15$ & $18 / 12$ & $24-45$ & 12 & $2000 \mathrm{EPA}$ & PANSS & $\downarrow$ & $\mathrm{BZ}$ & $\mathrm{BZ}$ & $\downarrow$ & - \\
\hline Fenton et al., 2001 & $43 / 44$ & $53 / 34$ & $18-65$ & 16 & $3000 \mathrm{EPA}$ & $\begin{array}{l}\text { PANSS, } \\
\text { AIMS, SAS, } \\
\text { MADRS, CGI }\end{array}$ & $\mathrm{BZ}$ & $\mathrm{BZ}$ & $\mathrm{BZ}$ & $\mathrm{BZ}$ & $\mathrm{BZ}$ \\
\hline Emsley et al., 2002 & $20 / 20$ & bd & $18-55$ & 12 & $3000 \mathrm{EPA}$ & PANSS, ESRS & BZ & BZ & $\downarrow$ & $\downarrow$ & $\begin{array}{c}\text { ESRS: } \\
\text { ESRS: } \downarrow \\
\text { dyskinesias } \\
\end{array}$ \\
\hline $\begin{array}{l}\text { Peet \& Horrobin, } \\
2002\end{array}$ & $\begin{array}{l}31 / 29 \\
28 ; 27\end{array}$ & $39 / 76$ & $18-70$ & 12 & $\begin{array}{l}1000 / 2000 / \\
3000 / 4000 \\
\text { EPA }\end{array}$ & $\begin{array}{l}\text { PANSS, } \\
\text { MADRS, } \\
\text { AIMS, BAS, } \\
\text { SAS }\end{array}$ & BZ & BZ & $\downarrow * *$ & $\downarrow$ & BZ \\
\hline $\begin{array}{l}\text { Ammingeret al., } \\
2010\end{array}$ & $41 / 40$ & $54 / 27$ & $13-25$ & 12 & $\begin{array}{l}700 \text { EPA + } 480 \\
\text { DHA }\end{array}$ & $\begin{array}{l}\text { PANSS, } \\
\text { MADRS, GAF }\end{array}$ & $\downarrow$ & $\downarrow$ & $\downarrow$ & $\downarrow$ & $\uparrow \mathrm{GAF}$ \\
\hline Bentsen et al., 2013 & $25 / 18$ & bd & $18-39$ & 16 & 2000 EPA & PANSS & $\downarrow$ & $\mathrm{BZ}$ & $\mathrm{BZ}$ & $\downarrow$ & - \\
\hline $\begin{array}{l}\text { Jamilian et al., } \\
2014\end{array}$ & $30 / 30$ & $29 / 31$ & $15-55$ & 8 & & PANSS & $\mathrm{BZ}$ & $\mathrm{BZ}$ & $\downarrow$ & $\downarrow$ & - \\
\hline Emsley et al., 2014 & $21 / 12$ & $9 / 24$ & $18-48$ & $\leq 104$ & $\begin{array}{l}2000 \text { EPA + } \\
1000 \text { DHA + } \\
\text { ALA } 300\end{array}$ & $\begin{array}{l}\text { PANSS, CGI, } \\
\text { SOPS, CDSS, } \\
\text { SOFAS, } \\
\text { WHOQOL- } \\
\text { BREF, ESRS, } \\
\text { MATRICS }\end{array}$ & BZ & BZ & BZ & BZ & BZ \\
\hline $\begin{array}{l}\text { Amminger et al., } \\
2015\end{array}$ & $41 / 40$ & $54 / 27$ & $13-25$ & 12 & $\begin{array}{l}700 \text { EPA + } 480 \\
\text { DHA }\end{array}$ & $\begin{array}{l}\text { PANSS, } \\
\text { MADRS, GAF }\end{array}$ & $\downarrow$ & $\downarrow$ & $\downarrow$ & $\downarrow$ & $\uparrow \mathrm{GAF}$ \\
\hline $\begin{array}{l}\text { Pawełczyk } \\
\text { et al., } 2016\end{array}$ & $36 / 35$ & $29 / 42$ & $16-35$ & 26 & $\begin{array}{l}1320 \text { EPA + } \\
880 \text { DHA }\end{array}$ & $\begin{array}{l}\text { PANSS, GAF, } \\
\text { CDSS, CGI-S }\end{array}$ & BZ & BZ & $\downarrow$ & $\downarrow$ & $\begin{array}{l}\downarrow \mathrm{CDSS}, \\
\uparrow \mathrm{GAF}, \\
\uparrow \mathrm{CGI}-\mathrm{S}\end{array}$ \\
\hline
\end{tabular}

SG - study group, CG - control group, F - female , M - male; * - Group supplemented with DHA; ** Patients treated with clozapine 


\section{Conclusions}

Evidence from preclinical studies confirm that $\omega-3$ EFAs may, in a positive way, influence adverse effects in the central nervous system caused by the onset of psychotic symptoms. However, the results of randomized controlled human studies in this field are not conclusive. Contradictions may result from methodological heterogeneity of these studies - duration of illness of participants, their current status, form and dose of $\omega-3$ EFAs and length of supplementation. Low risk of adverse side effects associated with the supplementation of $\omega$-3EFAs, as compared to traditional forms of antipsychotic treatment of schizo- phrenia makes these acids increasingly seen as a promising and safe treatment method, for both the treatment of acute episodes as well as preventing relapse of schizophrenia. The improvement in dysfunctions observed in the course of mental disorders, among others cognitive disorders, metabolic disorders, modifies the course of disease. Especially promising seems to be the role of $\omega-3$ EFAs in the early stages of the disease (high-risk groups, the first psychotic episode). Initial reports confirm the validity of further well-designed studies designed to confirm the efficacy and safety of interventions using the EFAs in different groups of patients with schizophrenia.

\section{Wstęp}

Kwasy tłuszczowe omega $3(\omega-3)$ należą do grupy niezbędnych nienasyconych kwasów tłuszczowych (NNKT). Oznacza to, że organizm ludzki nie wykazuje zdolności ich syntezy i konieczne jest dostarczenie ich z pożywieniem [1]. Historia NNKT sięga lat 30. XX wieku, kiedy amerykańscy naukowcy Burr i Evans zaobserwowali objawy chorobowe u szczura spowodowane niedoborem NNKT. Przełomem w badaniach nad NNKT okazały się datowane na lata 80. XX wieku doniesienia o roli $\mathrm{w}$ prewencji chorób sercowonaczyniowych [2]. Pierwsze przesłanki o korelacjach pomiędzy NNKT i zdrowiem psychicznym pojawiły się po roku 2000, a liczba publikacji w tym zakresie stale rośnie. Zainteresowanie wynika z wysokiej zawartości NNKT w mózgu oraz ich wpływu na funkcje OUN [3]. NNKT $\omega-3$ mogą korzystnie wpływać na przebieg wielu współtowarzyszących chorobom psychicznym zaburzeń. Istotną rolę NNKT $\omega-3$ przypisuje się w aspekcie profilaktyki i terapii składowych zespołu metabolicznego dyslipidemii, zaburzeń gospodarki węglowodanowej oraz nadciśnienia tętniczego [4], a także zaburzeń funkcji poznawczych $[4,5]$. Wykazano także rolę NNKT $\omega$-3 w modulacji układu odpornościowego [6], w tym regulacji poziomów cytokin przeciw i prozapalnych $[7,8]$. Ze względu na swoją wielokierunkowość działania NNKT $\omega-3$ są godną zainteresowania formą koterapii zaburzeń psychicznych, w tym schizofrenii.

\section{Cel}

Celem artykułu jest przegląd literatury dotyczącej klinicznego zastosowania niezbędnych nienasyconych kwasów tłuszczowych (NNKT) z rodziny omega $3(\omega-3)$, ze Szczególnym uwzględnieniem kwasów dokozaheksaenowego (DHA) i eikozapentaenowego (EPA), w terapii schizofrenii oraz zaburzeń ze spektrum schizofrenii.

\section{Metoda}

Dokonano przeglądu dostępnych prac dotyczących poruszanej problematyki wykorzystując elektroniczne bazy danych Medline i Google Scholar, używając deskryptora czasowego 2000 - wrzesień 2016 oraz słów-kluczy: schizofrenia, omega 3, niezbędne nienasycone kwasy tłuszczowe omega 3, kwas dokozaheksaenowy, kwas eikozapentaenowy, kwas $\alpha$-linolenowy, randomizowane badanie kliniczne, suplementacja.

Praca została podzielona na następujące, powiązane logicznie podrozdziały:

1. Dane z badań przedklinicznych

2. Dane $\mathrm{z}$ randomizowanych kontrolowanych badań (RCTs) dotyczące skuteczności i bezpieczeństwa NNKT $\omega-3 \mathrm{w}$ badaniach (zestawienie analizowanych prac przedstawia tab.1):

2.1. High risk study

2.2. W okresie I epizodu psychotycznego

2.3. W zapobieganiu kolejnym epizodom psychotycznym

2.4. W monoterapii

2.5. W lekooporności

2.6. Dane z meta-analiz

2.7. Obserwowane efekty uboczne

3. Podsumowanie

\section{Dane $\mathrm{z}$ badań przedklinicznych}

Istotna część wiedzy z zakresu dziedzin biomedycznych rozpoczyna się od badań bazujących na modelach zwierzęcych. Ocena skuteczności stosowanych interwencji oraz ich bezpieczeństwa pozwalają na późniejsze przeprowadzanie badań z udziałem ludzi. Badania modelowe, w których ocenie podlega efektywność terapii schizofrenii dostarcza pewnych trudności [9]. Brak obiektywnych markerów zaburzeń psychicznych, diagnoza stawiana w oparciu o stwierdzenie występowania objawów psychopatologicznych i niska specyficzność objawów, uniemożliwiają stworzenie optymalnego modelu zwierzęcego w odniesieniu do tej grupy zaburzeń [10]. 
W badaniach interwencyjnych na modelu zwierzęcym oceniających wpływ suplementacji NNKT $\omega$-3 na objawy schizofrenopodobne, choroba ta u zwierząt indukowana była poprzez iniekcję ketaminy [11-14] lub amfetaminy [15]. Suplementacja NNKT $\omega-3$ poprzedzała, następującą w końcowym etapie doświadczenia, indukcję objawów [11-15].

W badaniu Zugano i wsp. podanie NNKT $\omega-3$ hamowało aktywność enzymu biorącego udział w hydrolizie acetylocholiny (acetylocholinoesterazy) w korze przedczołowej, prążkowiu oraz hipokampie [13]. Zaburzenia w transmisji cholinergicznej i spadek stężenia neuroprzekaźnika dodatnio korelują z zaburzeniem funkcji poznawczych $[16,17]$.

W innym badaniu sprawdzano wpływ NNKT $\omega$-3 na poziomy BDNF oraz związków o charakterze prozapalnym - interleukiny-1 $\beta$ i interleukiny-6 [14]. U pacjentów cierpiących na schizofrenię obserwowana jest nadmierna sekrecja cytokin prozapalnych. Substancje te wykazują zdolność do przenikania bariery krew-mózg i indukcji zmian w OUN [18]. BDNF bierze udział $\mathrm{w}$ promowaniu plastyczności i wzrostu neuronów, a osoby cierpiące na schizofrenię mają znamiennie niższe stężenia BDNF w osoczu oraz surowicy krwi w porównaniu z osobami zdrowymi [19]. W badaniu modelowym NNKT $\omega-3$ nie wpłynęły na sekrecję interleukin. Autorzy badania wykazali natomiast, że suplementacja NNKT $\omega$-3 zapobiegała spadkowi BDNF w korze przedczołowej szczurów [14].

Także Gama i wsp. obserwowali spowodowane suplementacją NNKT $\omega-3$ zmiany w poziomie BDNF. Suplementacja spowodowała wzrost poziomu BDNF. Nie zaobserwowano natomiast zmian w ekspresji mRNA BDNF. U szczurów poddanych interwencji wykazano także spadek nasilenia objawów pozytywnych, negatywnych oraz zaburzeń funkcji kognitywnych i nadaktywności lokomotorycznej. Polepszeniu uległy także pamięć krótkotrwała, długotrwała, robocza oraz spowodowana chorobą zmniejszona interakcja z innymi osobnikami [11].

Wpływ kwasów NNKT $\omega$-3 na hamowanie przedimpulsowe (PPI), czyli osłabienie reakcji spowodowanej słabą stymulacją poprzedzającą silniejszy bodziec, badali Zugano i wsp. Suplementacja spowodowała częściowe zniesienie PPI. W badaniu NNKT $\omega-3$ przeciwdziałały spadkowi aktywności peroksydazy glutationowej (GPx) w prążkowiu i hipokampie oraz hamowały nadaktywności GPx w korze przedczołowej. Suplementacja nasiliła spowodowany działaniem ketaminy wzrost dysmutazy ponadtlenkowej (SOD) w hipokampie. W korze przedczołowej NNKT $\omega$-3 zmniejszyły obserwowaną $u$ chorych szczurów nadaktywność SOD. Zwierzęta z grupy badanej charakteryzowały się także niższą aktywnością katalazy (CAT) $\mathrm{w}$ korze przedczołowej $\mathrm{w}$ porównaniu $\mathrm{z}$ grupą z objawami chorobowymi oraz grupą kontrolną. Zdaniem autorów obserwowana w badaniu heterogenność regulacji enzymatycznej związana była z zależną od obszaru mózgu aktywnością enzymów antyoksydacyjnych oraz specyficznym, względem struktur OUN działaniem NNKT $\omega-3$ [12]. Autorzy badania wykazali także protekcyjne działanie kwasu eikozapentaenowego (EPA) i kwasu dokozaheksaenowego (DHA) w zakresie niekorzystnych i obserwowanym wśród pacjentów leczonych przeciwpsychotycznie zjawisk peroksydacji lipidów oraz białek. Suplementacja zapobiegała uszkodzeniu lipidów w hipokampie i prążkowiu oraz uszkodzeniu białek w korze przedczołowej i prążkowiu [12].

W badaniach porównywano także efektywność działania NNKT $\omega-3$ z innymi formami farmakoterapii. Szczury, które poddano suplementacji charakteryzowały się lepszymi wynikami w teście oceniającym pamięć deklaratywną i orientacją przestrzenną w porównaniu do zwierząt nieleczonych. Jednakże efekt ten zależny był od zastosowanej substancji badanej. Szczury otrzymujące EPA i DHA miały istotnie lepsze wyniki w porównaniu do otrzymujących risperidon oraz podobne do zwierząt otrzymujących COX-2 selektywny niesteroidowy lek przeciwzapalny-celecobix. Suplementacja NNKT $\omega$-3 wpłynęła na polepszenie pamięci operacyjnej oraz pamięci rozpoznawczej (czasu niezbędnego do zbadania nieznanego osobnika) zwierząt [15].

Dane z badań na modelu zwierzęcym wykazały, iż NNKT $\omega-3$ wywierają pozytywny wpływ na redukcję objawów psychopatologicznych oraz patologicznych zmian biochemicznym mózgu w schizofrenii. Wnioski $\mathrm{z}$ badań przedklinicznych powinny być traktowane $\mathrm{z}$ dużą ostrożnością, a ich wyniki nie powinny być bezpośrednio ekstrapolowane na organizm ludzki. Metody te posiadają pewne ograniczenia, przede wszystkim bazują na założeniu, że struktura oraz funkcje mózgu zwierząt i ludzi są podobne, a mechanizm ich działania jest jednakowy. Budowa OUN człowieka różni się od OUN szczura. Podobne różnice dotyczą złożoności zachowań oraz procesów myślowych [20]. Suplementacja stosowana w powyższych badaniach wynosiła ok. 0,8 g NNKT $\omega-3$ / kg masy ciała zwierzęcia [11-15]. Stosując taką ilość NNKT $\omega-3$ u ludzi, pacjent o masie ciała $70 \mathrm{~kg}$ powinien otrzymać dawkę $\mathrm{w}$ wysokości 56 g, podczas gdy w stosowane w RCT dawki są znacznie mniejsze i mieszczą się w zakresie od 0,5 g do $4 \mathrm{~g}$.

\section{Dane $\mathrm{z}$ randomizowanych kontrolowanych badań (RCTs) dotyczących skuteczności i bezpieczeństwa NNKT $\omega$-3}

\subsection{High risk study}

Wyłącznie jedno badanie przeprowadzone przez Ammingera i wsp. w 2010 roku oceniało wpływ suplementacji NNKT $\omega-3 \mathrm{w}$ prewencji zaburzeń psychotycznych w grupie podwyższonego ryzyka rozwoju psychozy. 
Podczas 12 tygodniowej interwencji uczestnicy otrzymywali 1200 mg NNKT $\omega-3$ (700 mg EPA + 480 mg DHA) lub placebo w postaci oleju kokosowego. Pierwszorzędowym punktem końcowym badania było rozwinięcie zaburzenia psychotycznego. Stan zdrowia uczestników oceniano po 40 tygodniach. 76 spośród 81 pacjentów ukończyło badanie. U 2 osób z grupy badanej (4,9\%) nastąpiła progresja objawów choroby, a wśród grupy otrzymującej placebo progresję obserwowano u 11 osób (27,5\%). Suplementacja NNKT $\omega-3$ zredukowała całkowite nasilenie objawów psychopatologicznych mierzonych skalą PANSS, w tym we wszystkich jej podskalach: objawów pozytywnych, negatywnych i objawów ogólnych. W grupie badanej otrzymującej NNKT wykazano także poprawę funkcjonowania mierzoną skalą GAF w porównaniu z osobami otrzymującymi placebo [21].

Amminger i wsp. kontynuowali swoje badanie, oceniając długoterminowe działanie NNKT $\omega-3 \mathrm{w}$ grupie pacjentów wysokiego ryzyka [33]. Uzyskane przez autorów wyniki potwierdziły zaprezentowane w pierwszej publikacji [21] wnioski o protekcyjnym działaniu EPA i DHA. 7 lat po zakończeniu suplementacji u 4 (7,9\%) pacjentów z grupy przyjmującej NNKT oraz u 16 (40\%) pacjentów z grupy placebo pojawił się epizod psychotyczny. Wykazano istotne różnice $\mathrm{w}$ poprawie stanu klinicznego pacjentów. U pacjentów suplementowanych NNKT $\omega$-3 obserwowano poprawę funkcjonowania w skali GAF oraz objawów psychopatologicznych mierzonych skalą PANSS oraz wszystkich jej podskali w porównaniu z grupą placebo. W trakcie trwającego 7 lat okresu obserwacji 10 z 34 (29,4 \%) osób z grupy badanej przyjmowało leki przeciwpsychotyczne. W grupie placebo środki te zastosowało 19 z 35 (54,3\%) pacjentów [33].

\subsection{I epizod}

W 2016 roku Pawełczyk i wsp. opublikowali wyniki RCT $\mathrm{w}$ grupie 71 pacjentów z pierwszym epizodem schizofrenii. W czasie 26 tygodniowej interwencji uczestnicy otrzymywali 2200 mg NNKT $\omega-3$ (1320 mg EPA + 880 mg DHA) lub oliwę z oliwek jako placebo. Badanie ukończyło 65 uczestników. Po 6 miesięcznej interwencji obserwowano znamienny (25\%) spadek nasilenia objawów psychopatologicznych oraz podskali objawów ogólnych mierzonych skalą PANSS. Odpowiedź na leczenie obserwowano u 33,3\% osób leczonych NNKT $\omega$-3 w porównaniu z 5,7\% osobami przyjmującymi placebo. Wykazano także zmniejszenia objawów depresyjnych mierzonych za pomocą skali CDSS, wzrost funkcjonowania (skala GAF) oraz poprawę ogólnego wrażenia klinicznego (skala CGI-S) [22].

\subsection{Zapobieganie kolejnym epizodom psychotycznym}

Dotychczas, najwięcej danych dotyczących wpływu suplementacji NNKT $\omega-3$ na przebieg schizofrenii pocho- dzi z badań, w których NNKT $\omega$-3 stosowano jako leczenie uzupełniające standardową farmakoterapię. Pierwszorzędowym punktem końcowym badań był stan kliniczny oraz nasilenie objawów psychopatologicznych pacjentów.

Fenton i wsp. suplementowali NNKT $\omega$-3 u grupy pacjentów ze schizofrenią lub zaburzeniami schizoafektywnymi. 34 pacjentów (39\%) przyjmowało risperidon, olanzapinę lub kwetiapinę, 24 pacjentów (28\%) przyjmowało klozapinę, natomiast 19 pacjentów (22\%) stosowało dwa leki przeciwpsychotyczne. Suplementacja EPA w ilości 3000 mg trwała 16 tygodni, a badanie ukończyło 87 spośród 90 osób. Autorzy nie wykazali korzystnych efektów płynących z suplementacji NNKT $\omega$-3 [23].

Peet i wsp. porównywali skuteczność kliniczną 2000 mg EPA i 2000 mg DHA u 55 pacjentów. Jako placebo użyto oleju kukurydzianego. Autorzy badania nie podali informacji dotyczącej stosowanej przez uczestników badania farmakoterapii. Trwającą 12 tygodni interwencję ukończyło 45 osób. Grupa otrzymująca EPA wykazała istotne obniżenie nasilenia objawów psychopatologicznych w porównaniu do grupy kontrolnej oraz podskali objawów pozytywnych skali PANSS w porównaniu do grupy suplementowanej DHA [24].

W badaniu Emsleya i wsp. wzięło udział 40 pacjentów. 18 (45\%) spośród pacjentów przyjmowało klozapinę, pozostali uczestnicy badania stosowali leki przeciwpsychotyczne I generacji. Grupa badana suplementowała 3000 mg EPA przez okres 12 tygodni, a jako placebo wykorzystano parafinę. Autorzy oceniali także nasilenie objawów pozapiramidowych. Pacjenci suplementowani EPA wykazali istotny spadek nasilenia objawów psychopatologicznych oraz podskali objawów ogólnych skali PANSS w porównaniu do pacjentów otrzymujących placebo. Ponadto suplementacja EPA spowodowała spadek nasilenia dyskinez [25].

Bentsen i wsp. poza NNKT $\omega$-3 badali wpływ suplementacji dwóch związków o charakterze antyoksydacyjnym - witamin C i E. 99 pacjentów cierpiących na zaburzenia ze spektrum schizofrenii przydzielono losowo do jednej z grup - placebo, suplementującej NNKT $\omega-3$, suplementującej witaminy lub suplementującej NNKT $\omega-3$ i witaminy jednocześnie. Zastosowana dawka EPA wynosiła $2000 \mathrm{mg}$, a jako placebo użyto oleju parafinowego. Spośród pacjentów biorących udział w interwencji 51 (52\%) przyjmowało klozapinę lub olanzapinę. Okres suplementacji trwał 16 tygodni, a badanie ukończyło 72 osób. U pacjentów suplementowanych EPA obserwowano spadek nasilenia objawów psychopatologicznych mierzonych skalą PANSS oraz objawów pozytywnych. Efekt ten obserwowano jedynie u pacjentów z niskim wyjściowym stanem odżywienia NNKT $\omega-3$ [26].

Badanie Jamiliana i wsp. trwało 8 tygodni i wzięło w nim udział 60 osób. Zakwalifikowani do badania pa- 
cjenci przyjmowali olanzapinę, risperidon lub klozapinę. 30 pacjentów, otrzymywało 1000 mg NNKT $\omega$-3. Nasilenie objawów mierzono na początku badania, po 2, 4, 6 oraz 8 tygodniach od rozpoczęcia suplementacji. Po tygodniu 4 wykazano spadek nasilenia objawów podskali ogólnej skali PANSS, a po 6 tygodniu wykazano spadek nasilenia objawów psychopatologicznych skali PANSS [27].

\subsection{Efektywność monoterapii NNKT}

Skuteczność NNKT $\omega-3$ jako monoterapii schizofrenii oceniono dotychczas $w$ dwóch badaniach: Peet i wsp. w 2001 [24] oraz Emsley i wsp. w 2002 roku [25]. W badaniu przeprowadzonym przez Peet i wsp. uczestniczyła grupa 30 nowozdiagnozowanych lub w okresie kolejnego epizodu choroby pacjentów z rozpoznaniem schizofrenii: 9 osób nigdy nie przyjmowało neuroleptyków, a pozostali uczestnicy badania nie stosowali farmakoterapii przez okres minimum 2 tygodni przed rozpoczęciem interwencji. Pacjenci otrzymywali $2000 \mathrm{mg}$ EPA lub tę samą ilość oleju kukurydzianego (jako placebo) przez okres 3 miesięcy. Badanie ukończyło 26 pacjentów. W grupie otrzymującej EPA po zakończeniu protokołu 6 z 14 pacjentów nie wymagało leczenia przeciwpsychotycznego. W grupie kontrolnej wszyscy (12 osób) uczestnicy powrócili do tradycyjnej formy terapii. Pacjenci z grupy badanej wykazywali znamienną redukcję objawów psychopatologicznych (wynik całkowity) w skali PANSS oraz podskali objawów pozytywnych. Odpowiedź na leczenie, rozumiana jako ponad $50 \%$ redukcja objawów w podskali objawów pozytywnych PANSS, wykazano u 2 pacjentów z grupy placebo oraz 8 pacjentów suplementujących EPA [24].

Drugim RCT, w którym badano działanie NNKT $\omega-3$ jako jedynej formy terapii schizofrenii, była przeprowadzona przez Emsleya i wsp. interwencja z udziałem 33 pacjentów po I epizodzie choroby, u których leczenie przeciwpsychotyczne przyniosło oczekiwane rezultaty. Pacjenci przyjmowali NNKT $\omega-3 \mathrm{w}$ ilości 3300 mg (2000 mg EPA + 1000 mg DHA + 300 mg ALA) lub oliwę z oliwek jako placebo przez okres 6 miesięcy. Nawrót choroby zaobserwowano u 19 spośród 21 uczestników z grupy badanej (90\%) w porównaniu do 9 z 12 (75\%) osób $\mathrm{z}$ grupy placebo. Jeden pacjent z grupy przyjmującej NNKT $\omega-3$ pozostał $\mathrm{w}$ remisji przez okres 2 lat. Nie wykazano różnicy w długości trwania remisji w podgrupach [28].

\subsection{Skuteczność NNKT w przypadku stwierdzanej lekooporności w schizofrenii}

Wśród 115 uczestników badania przeprowadzanego przez Peeta i Horrobina znalazła się 31 osobowa grupa pacjentów leczonych klozapiną. U włączonych do badania, pomimo stosowanej farmakoterapii, obserwowano wysokie nasilenie objawów psychopatologicznych (średnio 78 punktów w skali PANSS). Zastosowana w badaniu dawka EPA wynosiła 1000, 2000 oraz 4000 mg, a jako placebo użyto parafiny. Po 12 tygodniowej suplementacji u pacjentów przyjmujących EPA wykazano spadek nasilenia objawów psychopatologicznych w skali PANSS oraz w podskali objawów ogólnych w porównaniu z grupą przyjmującą placebo. Efekt osiągnięto w grupie otrzymującej $2000 \mathrm{mg}$ [29]. Jednym z efektów ubocznych stosowania klozapiny jest wzrost poziomu triglicerydów we krwi [30]. W badaniu suplementacja EPA w ilości 2000 lub 4000 mg przyczyniła się do niwelowania niekorzystnego działania farmakoterapii [29].

\subsection{Dane z metaanaliz}

Pierwszą metaanalizę dotyczącą NNKT w schizofrenii przeprowadzono w 2006. Autorzy na podstawie trzech włączonych publikacji (grupa pacjentów $n=152$ ) wykazali znamienny spadek objawów psychopatologicznych w grupie suplementującej EPA w porównaniu do placebo 6.33 (95\%CI: -11.34 - -1.32) [31].

W 2012 roku Berger i wsp. poddali analizie dane z 7 badań oceniających kliniczną skuteczność EPA u pacjentów ze schizofrenią (leczonych przewlekle oraz w pierwszym epizodzie choroby). Meta-analizą objęto 167 pacjentów przyjmujących placebo oraz 168 suplementowanych EPA. Autorzy nie wykazali korzystnego efektu suplementacji EPA u pacjentów cierpiących na schizofrenię. Autorzy we wnioskach zasugerowali, iż ze względu na zbyt małą liczbę dowodów, szczególnie dotyczących długoterminowej suplementacji oraz stosowania NNKT $\omega-3$ w zapobieganiu nawrotom po pierwszym epizodzie psychotycznych potrzebne są dalsze badania w tym zakresie [32].

\subsection{Obserwowane objawy uboczne podczas stosowania NNKT $\omega$-3}

W dwóch badaniach objawy uboczne stosowania NNKT $\omega$-3 oceniano przy użyciu skali Udvalg for Kliniske Undersøgelser [21, 22]. Pawełczyk i wsp. wykazali, iż pacjenci suplementujący NNKT $\omega-3$ wykazywali większą skłonność do zaparć w porównaniu do pacjentów przyjmujących placebo [22]. W badaniu Ammingera nie obserwowano różnic w zgłaszanych objawach ubocznych między badanymi grupami [21]. Bentsen i wsp., za pośrednictwem skali USERS (UKU Side Effect Rating Scale) nie wykazali niekorzystnych efektów suplementacji NNKT $\omega-3$ [26]. Peet i Horrobin mierzyli objawy uboczne suplementacji za pośrednictwem skali LUNSERS (The Liverpool University Neuroleptic Side Effect Rating Scale), a wyniki nie różniły się między grupami. Najczęściej zgłaszanymi objawami niepożądanymi były łagodne biegunki oraz nudności [29]. 
Tab. 1 Randomizowane kontrolowane badania kliniczne z podwójnie ślepą próbą (RCTs) - skuteczność NNKT $\omega-3$ $\mathrm{w}$ terapii schizofrenii

\begin{tabular}{|c|c|c|c|c|c|c|c|c|c|c|c|}
\hline \multirow[b]{3}{*}{ AUTOR, ROK } & \multicolumn{3}{|c|}{ UCZESTNICY BADANIA } & \multicolumn{3}{|c|}{ SUPLEMENTACJA } & \multicolumn{5}{|c|}{ WYNIK } \\
\hline & \multirow[b]{2}{*}{$\begin{array}{c}\mathrm{N} \\
(\mathrm{GB} / \mathrm{G} \\
\mathrm{K})\end{array}$} & \multirow[b]{2}{*}{$\mathrm{K}: \mathrm{M}$} & \multirow[b]{2}{*}{ WIEK } & \multirow[b]{2}{*}{$\begin{array}{l}\text { OKRES } \\
\text { (TYG) }\end{array}$} & \multirow[b]{2}{*}{$\begin{array}{l}\text { DAWKA } \\
\text { (MG/D) }\end{array}$} & \multirow[b]{2}{*}{$\begin{array}{c}\text { NARZĘDZIA } \\
\text { DO OCENY } \\
\text { EFEKTYWNOŚCI }\end{array}$} & \multicolumn{4}{|c|}{ PANSS } & \multirow[t]{2}{*}{$\begin{array}{l}\text { INNE } \\
\text { SKALE }\end{array}$} \\
\hline & & & & & & & 㸚 & 岕 & 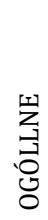 & 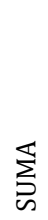 & \\
\hline Peet i wsp., 2001a & $\begin{array}{c}15 / 14 \\
/ 16^{*}\end{array}$ & $18 / 11$ & $31-56$ & 12 & $2000 \mathrm{EPA}$ & PANSS & $\downarrow$ & $\mathrm{BZ}$ & $\mathrm{BZ}$ & $\downarrow$ & - \\
\hline Peet $i$ wsp., $2001 b$ & $15 / 15$ & $18 / 12$ & $24-45$ & 12 & $2000 \mathrm{EPA}$ & PANSS & $\downarrow$ & $\mathrm{BZ}$ & $\mathrm{BZ}$ & $\downarrow$ & - \\
\hline Fenton i wsp., 2001 & $43 / 44$ & $53 / 34$ & $18-65$ & 16 & $3000 \mathrm{EPA}$ & $\begin{array}{l}\text { PANSS, AIMS, } \\
\text { SAS, MADRS, CGI }\end{array}$ & $\mathrm{BZ}$ & $\mathrm{BZ}$ & $\mathrm{BZ}$ & $\mathrm{BZ}$ & BZ \\
\hline Emsley i wsp., 2002 & $20 / 20$ & bd & $18-55$ & 12 & $3000 \mathrm{EPA}$ & PANSS, ESRS & $\mathrm{BZ}$ & BZ & $\downarrow$ & $\downarrow$ & $\begin{array}{l}\text { ESRS: } \\
\text { ESRS: } \downarrow \\
\text { dyskinez }\end{array}$ \\
\hline $\begin{array}{l}\text { Peet i Horrobin, } \\
2002\end{array}$ & $\begin{array}{l}31 / 29 \\
28 ; 27\end{array}$ & $39 / 76$ & $18-70$ & 12 & $\begin{array}{l}1000 / \\
2000 / \\
3000 / \\
4000 \mathrm{EPA}\end{array}$ & $\begin{array}{l}\text { PANSS, MADRS, } \\
\text { AIMS, BAS, SAS }\end{array}$ & $\mathrm{BZ}$ & $\mathrm{BZ}$ & $\begin{array}{l}* \\
*\end{array}$ & $\downarrow$ & $\mathrm{BZ}$ \\
\hline $\begin{array}{l}\text { Amminger } \\
\text { i wsp., } 2010\end{array}$ & $41 / 40$ & $54 / 27$ & $13-25$ & 12 & $\begin{array}{l}700 \mathrm{EPA}+ \\
480 \mathrm{DHA}\end{array}$ & $\begin{array}{l}\text { PANSS, MADRS, } \\
\text { GAF }\end{array}$ & $\downarrow$ & $\downarrow$ & $\downarrow$ & $\downarrow$ & $\uparrow \mathrm{GAF}$ \\
\hline Bentsen i wsp., 2013 & $25 / 18$ & bd & $18-39$ & 16 & $2000 \mathrm{EPA}$ & PANSS & $\downarrow$ & $\mathrm{BZ}$ & $\mathrm{BZ}$ & $\downarrow$ & - \\
\hline $\begin{array}{l}\text { Jamilian i wsp., } \\
2014\end{array}$ & $30 / 30$ & $29 / 31$ & $15-55$ & 8 & & PANSS & $\mathrm{BZ}$ & $\mathrm{BZ}$ & $\downarrow$ & $\downarrow$ & - \\
\hline Emsley i wsp., 2014 & $21 / 12$ & $9 / 24$ & $18-48$ & $\leq 104$ & $\begin{array}{l}2000 \mathrm{EPA} \\
+1000 \\
\text { DHA + ALA } \\
300\end{array}$ & $\begin{array}{l}\text { PANSS, CGI, } \\
\text { SOPS, CDSS, } \\
\text { SOFAS, } \\
\text { WHOQOL-BREF, } \\
\text { ESRS, MATRICS }\end{array}$ & $\mathrm{BZ}$ & $\mathrm{BZ}$ & $\mathrm{BZ}$ & $\mathrm{BZ}$ & $\mathrm{BZ}$ \\
\hline $\begin{array}{l}\text { Amminger i wsp., } \\
2015\end{array}$ & $41 / 40$ & $54 / 27$ & $13-25$ & 12 & $\begin{array}{l}700 \mathrm{EPA}+ \\
480 \mathrm{DHA}\end{array}$ & $\begin{array}{l}\text { PANSS, MADRS, } \\
\text { GAF }\end{array}$ & $\downarrow$ & $\downarrow$ & $\downarrow$ & $\downarrow$ & $\uparrow \mathrm{GAF}$ \\
\hline $\begin{array}{l}\text { Pawełczyk } \\
\text { i wsp., } 2016\end{array}$ & $36 / 35$ & $29 / 42$ & $16-35$ & 26 & $\begin{array}{l}1320 \mathrm{EPA} \\
+880 \mathrm{DHA}\end{array}$ & $\begin{array}{l}\text { PANSS, GAF, } \\
\text { CDSS, CGI-S }\end{array}$ & $\mathrm{BZ}$ & $\mathrm{BZ}$ & $\downarrow$ & $\downarrow$ & $\begin{array}{l}\downarrow \mathrm{CDSS}, \\
\uparrow \mathrm{GAF}, \\
\uparrow \mathrm{CGI}-\mathrm{S}\end{array}$ \\
\hline
\end{tabular}

GB - grupa badana, GK - grupa kontrolna, K - kobiety, M - mężczyźni; * - grupa suplementowana DHA; ** u pacjentów leczonych Klozapiną

\section{Podsumowanie}

Dowody płynące z badań przedklinicznych potwierdzają, że NNKT $\omega$-3 mogą, w pozytywny sposób, wpływać na niekorzystne zmiany w OUN wywołane wystąpieniem objawów psychotycznych. Jednak wyniki randomizowanych kontrolowanych badań z udziałem ludzi w tym zakresie nie są jednoznaczne. Sprzeczności wynikać mogą z heterogeniczności metodologicznej omawianych badań czasu trwania choroby uczestników, ich obecnego stanu, formy i stosowanej dawki NNKT $\omega$-3 oraz długości suplementacji. Niskie ryzyko niepożądanych objawów ubocznych związanych $\mathrm{z}$ suplementacją NNKT $\omega-3$, w porównaniu do tradycyjnych form leczenia przeciwpsychotycznego w schizofrenii sprawia, że kwasy te coraz częściej postrzegane są jako obiecujący i bezpieczny sposób terapii, zarówno w leczeniu ostrych epizodów, jak $\mathrm{i}$ zapobieganiu nawrotom $\mathrm{w}$ schizofrenii. Poprawa $\mathrm{w}$ zakresie obserwowanych $\mathrm{w}$ przebiegu zaburzeń psychicznych dysfunkcji m.in. zaburzeń funkcji kognitywnych, zaburzeń metabolicznych wpływa modyfikująco na przebieg choroby. Szczególnie obiecującą wydaje się być rola NNKT $\omega-3$ we wczesnych stadiach choroby (grupy wysokiego ryzyka, pierwszy epizod psychotyczny). Wstępne doniesienia potwierdzają słuszność dalszych, dobrze zaplanowanych badań mających potwierdzić skuteczność i bezpieczeństwo interwencji przy pomocy NNKT $w$ różnych grupach chorych na schizofrenię.

\section{Conflict of interest}

The authors have declared no conflict of interest.

\section{References:}

1. Nakamura M.T., Nara T.Y. Essential fatty acid synthesis and its regulation in mammals. Prostaglandins Leukot Essent Fatty Acids. 2003; 68(2): 145-50.

2. Holman R.T. The slow discovery of the importance of omega 3 essential fatty acids in human health. J Nutr. 1998; 128(2): 427-433.

3. Zeman M., Jirak R., Vecka M., Raboch J., Zak A. N-3 polyunsaturated fatty acids in psychiatric diseases: mechanisms and clinical data. Neuro Endocrinol Lett. 2012; 33(8): 736-48.

4. Lorente-Cebrián S., Costa A.G., Navas-Carretero S., Zabala M., Martínez J.A., Moreno-Aliaga M.J. Role of omega-3 fatty acids in obesity, metabolic 
syndrome, and cardiovascular diseases: a review of the evidence. J Physiol Biochem. 2013; 69(3): 633-51.

5. Eriksdotter M., Vedin I., Falahati F., Freund-Levi Y., Hjorth E., FaxenIrving G., Wahlund L.O., Schultzberg M., Basun H., Cederholm T., Palmblad J.. Plasma Fatty Acid Profiles in Relation to Cognition and Gender in Alzheimer's Disease Patients During Oral Omega-3 Fatty Acid Supplementation: The OmegAD Study. J Alzheimers Dis. 2015; 48(3): 805-12.

6. Dunstan J.A., Mori T.A., Barden A., Beilin L.J., Taylor A.L., Holt P.G., Prescott S.L. Fish oil supplementation in pregnancy modifies neonatal allergen-specific immune responses and clinical outcomes in infants at high risk of atopy: a randomized, controlled trial. J Allergy Clin Immunol. 2003; 112(6): 1178-84.

7. Gouveia T.L., Vieira de Sousa P.V., de Almeida S.S., Nejm M.B., Vieira de Brito J.M., Cysneiros R.M., de Brito M.V., Salu B.R., Oliva M.L., Scorza F.A, Naffah-Mazzacoratti Mda G.. High serum levels of proinflammatory markers during epileptogenesis. Can omega-3 fatty acid administration reduce this process? Epilepsy Behav. 2015; 51:300-5.

8. Farjadian S., Moghtaderi M., Kalani M., Gholami T., Hosseini Teshnizi S. Effects of omega-3 fatty acids on serum levels of T-helper cytokines in children with asthma. Cytokine. 2016; 85:61-6.

9. Marcotte E.R., Pearson D.M., Srivastava L.K. Animal models of schizophrenia: a critical review. J Psychiatry Neurosci. 2001; 26(5): 395-410.

10. Kilts C.D. The changing roles and targets for animal models of schizophrenia. Biol Psychiatry. 2001; 50(11): 845-55.

11. Gama C.S., Canever L., Panizzutti B., Gubert C., Stertz L., Massuda R., Pedrini M., de Lucena D.F., Luca R.D., Fraga D.B., Heylmann A.S., Deroza P.F., Zugno A.I. Effects of omega-3 dietary supplement in prevention of positive, negative and cognitive symptoms: a study in adolescent rats with ketamine-induced model of schizophrenia. Schizophr Res. 2012; 141(2-3): 162-7.

12. Zugno A.I., Chipindo H.L., Volpato A.M., Budni J., Steckert A.V., de Oliveira M.B., Heylmann A.S., da Rosa Silveira F., Mastella G.A., Maravai S.G., Wessler P.G., Binatti A.R., Panizzutti B., Schuck P.F., Quevedo J., Gama C.S. Omega-3 prevents behavior response and brain oxidative damage in the ketamine model of schizophrenia. Neuroscience. 2014; 259: 223-31.

13. Zugno A.I., Chipindo H., Canever L., Budni J., Alves de Castro A., Bittencourt de Oliveira M., Heylmann A.S., Gomes Wessler P., da Rosa Silveira F., Damázio L.S., Mastella G.A., Kist L.W., Bogo M.R., Quevedo J., Gama C.S. Omega-3 fatty acids prevent the ketamine-induced increase in acetylcholinesterase activity in an animal model of schizophrenia. Life Sci. 2015; 121:65-9.

14. Zugno A.I., Canever L., Mastella G., Heylmann A.S., Oliveira M.B., Steckert A.V., Castro A.A., dal Pizzol F., Quevedo J., Gama C.S.. Effects of omega-3 supplementation on interleukin and neurotrophin levels in an animal model of schizophrenia. An Acad Bras Cienc. 2015; 87 (2Suppl): 1475-86.

15. El-Sayed El-Sisi A., Sokkar S.S., El-Sayed El-Sayad M., Sayed Ramadan E., Osman E.Y. Celecoxib and omega-3 fatty acids alone and in combination with risperidone affect the behavior and brain biochemistry in amphetamine-induced model of schizophrenia. Biomed Pharmacother. 2016; 82: 425-31.

16. Watanabe T., Yamagata N., Takasaki K., Sano K., Hayakawa K., Katsurabayashi S., Egashira N., Mishima K., Iwasaki K., Fujiwara M. Decreased acetylcholine release is correlated to memory impairment in the Tg2576 transgenic mouse model of Alzheimer's disease. Brain Res. 2009; 1249: 222-8

17. Micheau J., Marighetto A. Acetylcholine and memory: a long, complex and chaotic but still living relationship. Behav Brain Res. 2011; 221(2): 424-9.

18. Potvin S., Stip E., Sepehry A.A., Gendron A., Bah R., Kouassi E. Inflammatory cytokine alterations in schizophrenia: a systematic quantitative review. Biol Psychiatry. 2008; 63(8): 801-8.
19. Fernandes B.S, Steiner J., Berk M., Molendijk M.L., Gonzalez-Pinto A., Turck C.W., Nardin P., Gonçalves C.A. Peripheral brain-derived neurotrophic factor in schizophrenia and the role of antipsychotics: meta-analysis and implications. Mol Psychiatry. 2015; 20(9): 1108-19.

20. Premack D. Human and animal cognition: continuity and discontinuity. Proc Natl Acad Sci U S A. 2007; 104(35): 13861-7.

21. Amminger G.P., Schäfer M.R., Papageorgiou K., Klier C.M., Cotton S.M., Harrigan S.M., Mackinnon A., McGorry P.D., Berger G.E. Long-chain omega-3 fatty acids for indicated prevention of psychotic disorders: a randomized, placebo-controlled trial. Arch Gen Psychiatry. 2010; 67(2): 146-54.

22. Pawelczyk T, Grancow-Grabka M, Kotlicka-Antczak M, Trafalska E, Pawełczyk A. A randomized controlled study of the efficacy of six-month supplementation with concentrated fish oil rich in omega-3 polyunsaturated fatty acids in first episode schizophrenia. J Psychiatr Res. 2016; 73: 34-44.

23. Fenton W.S., Dickerson F., Boronow J., Hibbeln J.R., Knable M. A placebocontrolled trial of omega-3 fatty acid (ethyl eicosapentaenoic acid) supplementation for residual symptoms and cognitive impairment in schizophrenia. Am J Psychiatry. 2001; 158(12): 2071-4.

24. Peet M., Brind J., Ramchand C.N., Shah S., Vankar G.K. Two double-blind placebo-controlled pilot studies of eicosapentaenoic acid in the treatment of schizophrenia. Schizophr Res. 2001; 49(3): 243-51.

25. Emsley R., Myburgh C., Oosthuizen P., van Rensburg S.J. Randomized, placebo-controlled study of ethyl-eicosapentaenoic acid as supplemental treatment in schizophrenia. Am J Psychiatry. 2002; 159(9): 1596-8

26. Bentsen H., Osnes K., Refsum H., Solberg D.K., Bøhmer T. A randomized placebo-controlled trial of an omega-3 fatty acid and vitamins $\mathrm{E}+\mathrm{C}$ in schizophrenia. Transl Psychiatry. 2013; 3:e335.

27. Jamilian H., Solhi H., Jamilian M. Randomized, placebo-controlled clinical trial of omega-3 as supplemental treatment in schizophrenia. Glob J Health Sci. 2014; 6(7): 103-8.

28. Emsley R., Chiliza B., Asmal L., du Plessis S., Phahladira L., van Niekerk E., van Rensburg S.J., Harvey B.H. A randomized, controlled trial of omega-3 fatty acids plus an antioxidant for relapse prevention after antipsychotic discontinuation in firstepisode schizophrenia. Schizophr Res. 2014; 158(1-3): 230-5.

29. Peet M., Horrobin D.F.; E-E Multicentre Study Group. A doseranging exploratory study of the effects of ethyleicosapentaenoate in patients with persistent schizophrenic symptoms. J Psychiatr Res. 2002; 36(1): 7-18.

30. Lally J., Gallagher A., Bainbridge E., Avalos G., Ahmed M., McDonald C. Increases in triglyceride levels are associated with clinical response to clozapine treatment. J Psychopharmacol. 2013; 27(4):401-3.

31. Joy C.B, Mumby-Croft R, Joy L.A. Polyunsaturated fatty acid supplementation for schizophrenia. Cochrane Database Syst Rev. 2006; (3):CD001257.

32. Fusar-Poli P., Berger G. Eicosapentaenoic acid interventions in schizophrenia: meta-analysis of randomized, placebo-controlled studies. J Clin Psychopharmacol. 2012; 32(2): 179-85.

33. Amminger G.P., Schäfer M.R., Schlögelhofer M., Klier C.M., McGorry P.D. Longer-term outcome in the prevention of psychotic disorders by the Vienna omega-3 study. Nat Commun. 2015; 6:7934.

\section{Correspondence address}

Joanna Róg

Faculty of Human Nutrition and Consumer Sciences,

Warsaw University of Life Sciences

e-mail: Joanna.rog@tlen.pl

Otrzymano: 02.11.2016

Zrecenzowano: 17.11.2016

Przyjęto do druku: 21.11.2016 